\title{
Measurement of Pollution Levels Caused by Heavy Metals of Vanadium, Nickel, Lead and Copper Using Bivalve Shells of Timoclea imbricata Species On Bahrakan Coast in Spring 2013
}

\author{
Seyyedeh Marzieh Moosavian ${ }^{1, *}$; Seyyed Mohammad Baghernabavi ${ }^{2}$; Elahe Zallaghi ${ }^{3}$; \\ Maryam Mohammadi Rouzbahani ${ }^{2}$; Elham Hosseini Panah ${ }^{1}$; Moloud Dashtestani ${ }^{1,2}$ \\ ${ }_{2}^{1}$ Khouzestan Science and Research Branch, Islamic Azad University, Ahvaz, IR Iran \\ ${ }_{2}^{2}$ Department of Environmental Science, Graduate School of the Environment, Science and Research Branch ,Islamic Azad University, Ahvaz, IR Iran \\ ${ }^{3}$ Young Researchers Club, Khouzestan Science and Research Branch, Islamic Azad University, Ahvaz, IR Iran \\ ${ }^{*}$ Corresponding author: Seyyedeh Marzieh Moosavian, Khouzestan Science and Research Branch, Islamic Azad University, Ahvaz, IR Iran. Tel: +98-9166028053, E-mail: moosavian. \\ mar@gmail.com
}

Received: May 25, 2014; Revised: July 26, 2014; Accepted: July 28, 2014

\begin{abstract}
Background: Bivalves have been used to study pollution level caused by heavy metals due to their biological characteristics. Bahrakan region includes Bahrakansar, Hendijan, Norouz and Soroush oil fields, and current information regarding sea management, especially from the protective aspect is very little.

Objectives:This study aimed to assess region pollution with heavy metals. For this purpose, pollution caused by heavy metals in bivalves was assessed and compared with the standard values.

Materials and Methods: Bivalve sampling was performed using Grab to determine the pollution content with heavy metals of vanadium, nickel, lead and copper in five different stations on 15 samples (3 samples for each station) in spring 2013. The digestion process was completed using the Yap method, then the concentrations of mentioned metals were measured using the ICP device in each of digested samples.

Results: Nickel $(13.12 \pm 6.07 \mathrm{mg} / \mathrm{kg})$ had the highest total average concentration and the lowest for lead $(1.15 \pm 0.28 \mathrm{mg} / \mathrm{kg})$. Concentrations of nickel, vanadium and lead were higher than the WHO international standards, but much lower for copper regarding the same standards. Concentrations of nickel and vanadium were higher than copper compared to FAO, but lower than lead regarding the presented allowable limit.

Conclusions: Nickel and vanadium had the highest concentration among other metals. Since these two metals are used as oil pollution parameters and the region is rich in oil, it can be concluded that oil pollution is present in the region. The existing oil pollution threatens all the living organisms in the area. Therefore, it would be of great importance to examine pollution sources of this region. The results can be used to constantly monitor the amount of heavy metals in bivalves of Timoclea imbricate species in this region.
\end{abstract}

Keywords:Nickel; Vanadium; Copper; Lead

\section{Background}

Nowadays, there is severe marine pollution including those caused by heavy metals. Reasons of water pollution include developing industries, urbanization near coasts, ship traffic, collisions, seabed drilling for oil and gas, agricultural fertilizers and their entering the seas through rivers, and urban or industrial wastewaters inflow into coastal waters. Heavy metals are especially important among various pollutants due to their toxic effects and ability to biologically accumulate in different species leading to biological magnification during their food chain. Heavy metals are stable pollutants and not biologically decomposable (1). Environmental evaluation and monitoring are required to determine the effects of pollutants and their concentrations in aquatic environments. The content in which aquatic environments are polluted can be determined by analyzing water, sediments and organ- isms (2). In food chain, metals can be transferred to higher levels. Pollutants exist in large quantities because of their biological accumulation and magnification in the body of aquatics. As humankind consume seafood, it is essential to know about natural metal quantities or at least their constant concentrations in an aquatic environment. This helps researchers to determine and evaluate possible metal pollution (3). Experimental studies showed that a portion of heavy metals accumulated in soft shellfish tissues may be influenced by physiologic processes inside the body. Meanwhile, concentration of accumulated metals is not too much in some tissues. It seems that they are less influenced by physiologic processes of the body. These tissues are more frequently used for biological monitoring in any region to achieve more precise results (4). Located between $25-30^{\circ} \mathrm{N}$ latitude and having a short distance to

Copyright (C) 2014, Ahvaz Jundishapur University of Medical Sciences. This is an open-access article distributed under the terms of the Creative Commons Attribution-NonCommercial 4.0 International License (http://creativecommons.org/licenses/by-nc/4.0/) which permits copy and redistribute the material just in noncommercial usages, provided the original work is properly cited. 
tropic of cancer have caused the coasts of Persian Gulf and coastal regions to be predominated by hot weather (5). The coastal region temperature varies from $5^{\circ} \mathrm{C}$ to $52^{\circ} \mathrm{C}$. There are seven hot summer months and five moderate fall and winter months. General climate of the studied coastal region is severe semi-arid according to Gossen's method (6). Bahrakan region includes Bahrakansar, Hendijan, Norouz and Soroush oil fields. Considering the great economic, social and natural importance of the region, current information about sea management especially from the protective aspect is very scarce $(7,8)$. The studied region is a part of Bahrakan coasts located northeast of the Persian Gulf. This part of the coast is connected to Hendijan through a $15-\mathrm{km}$ road. Crude oil extracted from five wells in 1973 was as much as 8335000 gallons. Bahrakan region is located in south of Hendijan. In few recent years, a large quantity of oil has been explored in this gulf through drilling submarine wells, and constructing numerous oil rigs. Facilities have made it easy for oil tankers to harbor, load and export oils abroad and it seems that this oil has a very good capability (9). Bahrakan coast beds are sandy-muddy and their eastern coasts are deeper. Consistency and stability of mud beds due to particulate sediments and organic matter density result in the presence of a large group of organisms such as mud crabs and various crustaceans, polychaetes, mollusks and oligochaetes in these beds. Despite their natural richness, mud beds and flats would be more brittle if subjected to environmental pollutants. Therefore, it is very important to investigate the way pollutants enter the mud beds. Numerous studies on bivalves have been conducted in different regions. on bivalve Perna viridis in Johore Strait and Dadollahi et al. (10) on bivalve Saccostrea cucullata on the coasts of Chabahar in both winter and summer. There are extensive studies by Oscar Ravera et al. (1934-2001) on bivalve Uniopictorum in both Levico and Culdonazzo Lakes (9).

Bivalvia are marine mollusca. Although they are mostly aquatic, some live in the sea and some in fresh waters. Bivalvia do not have radula and feed by passing water through and sifting microorganisms in the water. Bivalvia have two parts; right and left shells joined together via a ligament. The joint is located on the rear side and used by muscles to open and shut the valves. This part is used as seafood. Mollusca and bivalvia in particular, can purify water by removing oil pollutants, heavy metals, and radioactive materials using a special sifting mechanism (10). Shell is studied in tidewaters for its ecological purifying capability to remove lead, nickel, copper, and vanadium.

\section{Objectives}

This study aimed to determine water pollution of the region with heavy metals. For this purpose, pollution caused by heavy metals in bivalves was assessed and compared with standard values.

\section{Materials and Methods}

In spring 2013, bivalve sampling was performed in five stations for 15 samples. This was repeated three times for each station. Van Veen Grab was used with a cross section of $0.025 \mathrm{~m}^{2}$ to examine heavy metal pollutions (Figure 1). To increase the accuracy in choosing the stations after

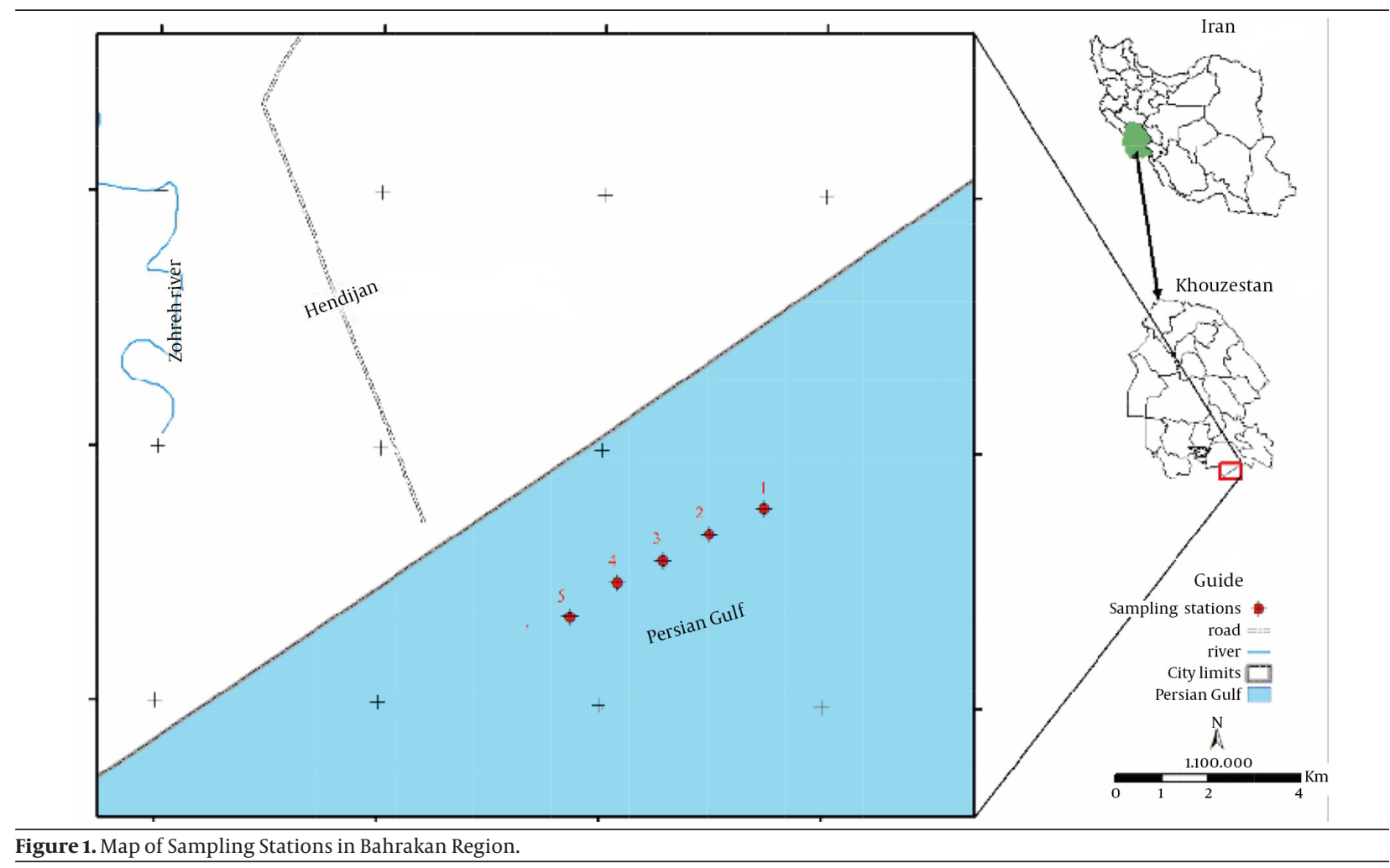


determining spatial location, geographical location and specification of each station were recorded by a GPS device (Table 1). Then samples obtained from each station were marked with attached labels on which specifications of the studied stations had been written and were transferred to the laboratory with a foam containing ice. Dried samples (shells) were first milled in the porcelain mortar and passed through a $63-\mu$ sieve, and then about $0.5 \mathrm{~g}$ shell dried samples were digested by $5 \mathrm{~mL}$ nitric acid $69 \%$ and Perchloric acid 60\% with a 3:1 ratio and placed under the hood with a crystal cap for 24 hours. After 24 hours, samples were first digested in $40^{\circ} \mathrm{C}$ for 1 hour, then by adding $5 \mathrm{~mL}$ diluted nitric acid $10 \%$ to clear the samples and then in $90^{\circ} \mathrm{C}$ for 2 hours in steam bath, and the digested samples were eventually filtered by Whatman filter papers No.1 and got volume by means of a $50 \mathrm{~mL}$ volumetric flask (11). Concentrations of metals in samples were determined using Inductively Coupled Plasma device. Results were illustrated for $\mathrm{mg} / \mathrm{kg}$ dry matter after unit conversion. Data analysis was performed using SPSS software. KolmogorovSmirnov test was used to study normal distribution of data. One-way analysis of variance (ANOVA) was used for general comparisons and Tukey test for multiple comparisons and significant differences with 99\% confidence level.

\section{Results}

The highest nickel absorption by Timoclea imbricata species was in station $5(22.40 \pm 0.03)$, the lowest in station 1 (4.63 \pm 0.03$)$ and nickel average in all stations was $(13.12 \pm 6.07) \mathrm{mg} / \mathrm{kg}$ dry weight (Figure 2). The highest vanadium absorption was in station $5(10.03 \pm 0.03)$, the lowest in station $1(4.96 \pm 0.01)$ and vanadium average in all stations was $(7.64 \pm 1.90) \mathrm{mg} / \mathrm{kg}$ dry weight (Figure 3 ). The highest copper absorption was in station 5 (8.00 \pm $0.01)$, the lowest in station $1(6.89 \pm 0.04)$ and the average copper in all stations was $(7.58 \pm 0.46) \mathrm{mg} / \mathrm{kg}$ dry weight (Figure 4). Furthermore, the highest lead absorption was in station $5(1.56 \pm 0.03)$ and the lowest was in station 1 $(0.72 \pm 0.02)$ and the average lead in all stations was (1.15 $\pm 0.28) \mathrm{mg} / \mathrm{kg}$ dry weight (Figure 5). In general, total average concentration of nickel was the highest (13.12 \pm 6.07$)$ and the lowest for lead $(1.15 \pm 0.28)$. The calculated average statistical parameters about 15 bivalve samples are presented in Table 2.

Table 1. Geographical Coordination of the Studied Stations According to Degree, Minute, and Second

\begin{tabular}{lcc}
\hline Station No. & North & East \\
\hline $\mathbf{1}$ & 300519 & 494712 \\
$\mathbf{2}$ & 300501 & 494628 \\
\hline $\mathbf{3}$ & 300442 & 494551 \\
$\mathbf{4}$ & 300426 & 494513 \\
$\mathbf{5}$ & 300401 & 494435 \\
\hline
\end{tabular}

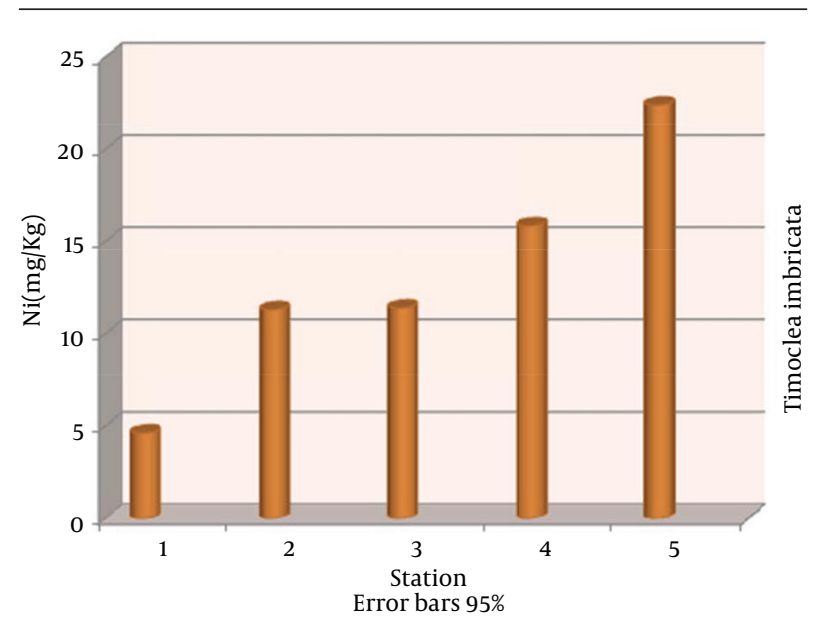

Figure 2. Nickel Concentration ( $\mathrm{mg} / \mathrm{kg}$ ) in Timoclea imbricata Shells in Different Stations

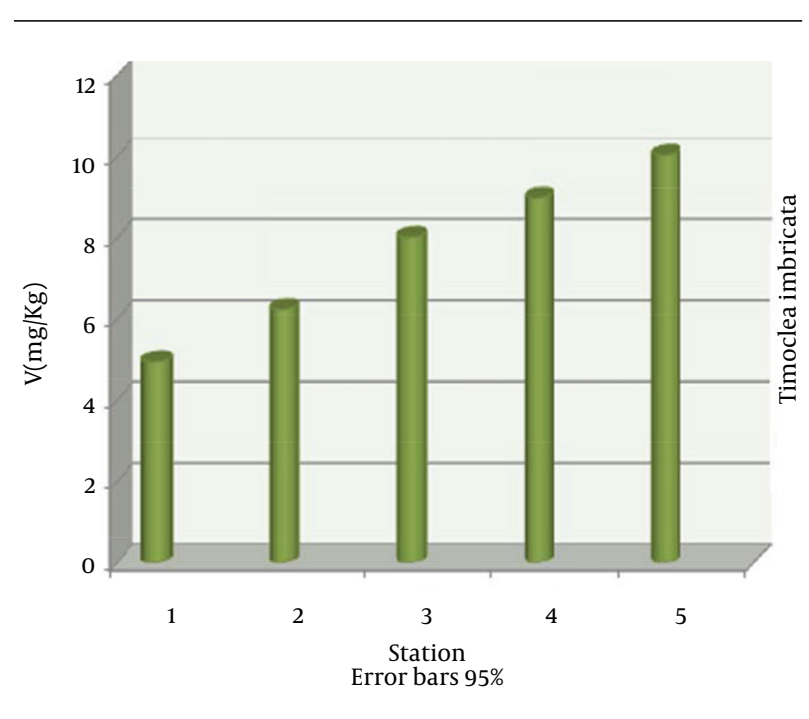

Figure 3. Vanadium Concentration $(\mathrm{mg} / \mathrm{kg})$ in Timoclea imbricata Shells in Different Stations

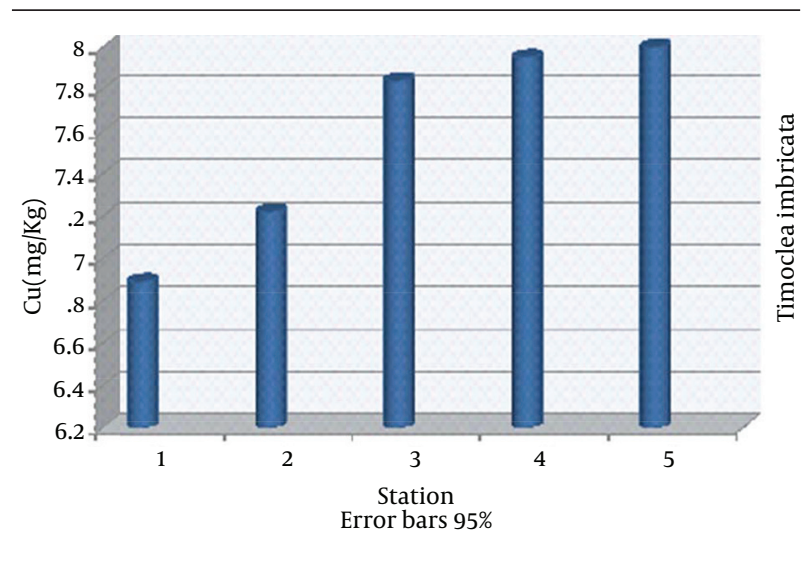

Figure 4. Copper Concentration $(\mathrm{mg} / \mathrm{kg})$ in Timoclea imbricata Shells in Different Stations 


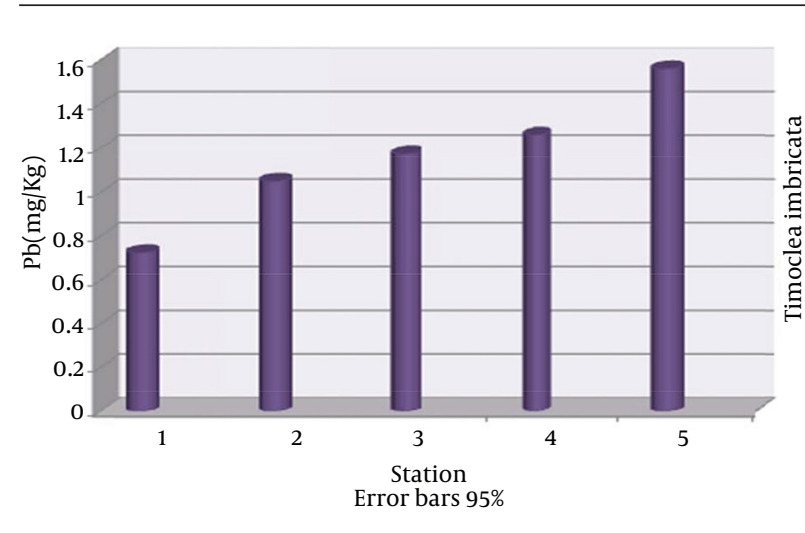

Figure 5. Lead Concentration $(\mathrm{mg} / \mathrm{kg})$ in Timoclea imbricata Shells in Different Stations

Table 2. Average Concentrations of Nickel, Vanadium, Copper and Lead for $\mathrm{mg} / \mathrm{kg}$ in Timoclea imbricata Shells for Different Stations

\begin{tabular}{lcccc}
\hline Element & Nickel & Vanadium & Lead & Copper \\
\hline Station & & & & \\
1 & $4.63 \pm 0.03$ & $4.96 \pm 0.01$ & $0.72 \pm 0.02$ & $6.89 \pm 0.04$ \\
\hline 2 & $11.31 \pm 0.04$ & $6.22 \pm 0.02$ & $1.05 \pm 0.02$ & $7.22 \pm 0.00$ \\
3 & $11.40 \pm 0.01$ & $8.00 \pm 0.00$ & $1.17 \pm 0.02$ & $7.84 \pm 0.01$ \\
4 & $15.85 \pm 0.05$ & $8.99 \pm 0.01$ & $1.26 \pm 0.04$ & $7.95 \pm 0.01$ \\
5 & $22.40 \pm 0.03$ & $10.03 \pm 0.03$ & $1.56 \pm 0.03$ & $8.00 \pm 0.01$ \\
$\begin{array}{l}\text { Average } \\
\pm \text { SD }\end{array}$ & $13.12 \pm 6.07$ & $7.64 \pm 1.90$ & $1.15 \pm 0.28$ & $7.58 \pm 0.46$ \\
\hline
\end{tabular}

\section{Discussion}

Numerous studies on bivalves have been conducted in different regions. In a study on bivalve Perna viridis in Johor Strait, nickel with 1.802 and lead with $1.345 \mathrm{mg} / \mathrm{kg}$ dry weight, had the highest and lowest metal concentrations in the considered species, respectively (12). This study is consistent with our findings. In a study on Saccostrea cucullata species by Dadollahi et al. in Chabahar coasts, vanadium had the minimum concentration, and lead and copper with the maximum concentrations of 46.15 and $16.67 \mathrm{mg}$ $\mathrm{kg}$ dry weight in summer and winter, respectively (10). In comprehensive studies by Oscar Ravera et al.(1934-2001) on bivalve Uniopictorum in both Levico and Culdonazzo lakes, it was revealed that copper and vanadium had the highest and lowest levels of 12 and $0.34 \mathrm{mg} / \mathrm{kg}$ dry weight, respectively. While, the minimum and maximum concentrations in the same lake were found for vanadium with 0.32 and nickel $9.36 \mathrm{mg} / \mathrm{kg}$ dry weight (9). They reported the high concentrations of vanadium and nickel in stations already polluted by oil hydrocarbons. They stated that pollution with both metals was due to oil contaminations caused by natural oil leakage and damage to pipelines (13). Our findings are opposite to numerous studies. Concentrations of nickel, vanadium and lead were higher than the WHO international standards, but lower than the standard limits for copper. Compared to FAO, concentrations of nickel and vanadium were higher, but lower for copper and lead regarding the standard limits. Average metal concentrations in standards are expressed as $\mathrm{mg} / \mathrm{kg}$ wet weight; however, concentrations obtained in this study were reported as $\mathrm{mg} / \mathrm{kg}$ dry weight. Therefore, metal concentrations obtained in dry tissues of shellfishes should be converted to concentrations in wet tissues. According to the performed calculations, metal concentration of wet wt. equals metal concentration for dry wt. multiplied to 0.149 and a relationship was established between metal concentrations in dry and wet weights. The obtained relationship in the current study was in agreement with (metal concentration in wet wt. $=$ metal concentration in dry wt. $\mathrm{x}$ 0.149) what stated by Wright et al. for Crassostrea species. Metal concentrations in dry weight could be converted to wet weight using the obtained formula (14).

Statistical expression of the obtained results is a suitable method to show pollutions in the region. A comparison was made between heavy metal content in provided samples in spring 2013 and the average statistical parameters. Concentration trend of mentioned metals in the studied region indicated that nickel, vanadium, copper and lead concentrations were the highest, respectively. Tukey test showed a significant difference in content of all metals in each of the five studied stations $(\mathrm{P}<0.05)$. In the study conducted on the species, total average concentration in nickel was the highest $(13.12 \pm 6.07)$ and the lowest for lead $(1.15 \pm 0.28)$.

This comparison showed that metals are adjusted because of intrinsic processes. Apparently, some processes are able to transfer unnecessary metals to portions with least adverse effects on shellfishes, so that shellfishes could survive in the presence of high concentrations in different tissues (15).

Significant difference between the contents of measured heavy metals in different stations indicated that pollution sources in this port are in the form of paint compounds. Copper and nickel exist in paint compounds including the ones used in ships and vessels. These elements also exist in urban wastewaters. Therefore, it seems that boat and vessel traffics as well as human and industrial wastewater discharged into waters of the region contaminated the region with copper and lead. In addition, lead also exists in vessel and boat gasoline, and due to heavy traffic, high level of wastewaters from the traffic enter the region (4, 16). It is likely that lead presence in shellfish shells can be caused by displacement of carbonations by lead ions in calcite (lime) compounds available in shells, because this metal has multiple times more affinity to carbonate ions than calcium ions in ionic state. Furthermore, since copper is an essential element in bivalves and such elements have high absorption levels, the presence of copper in bivalve shells would be justified.

Presence of nickel and vanadium in the region appears to be due to discharge and loading of minerals, oil leak- 
age from oil tankers and precipitations containing oil combustion products. Moreover, fishing and boating activities release oil compounds into the water. Besides, marine currents from other regions entering the coasts should be taken into consideration. On the other hand, burning fossil fuels, ship manufacturing and its exhausted fumes, vessel traffics and wastewaters, or oil contaminations dispersed across the coasts of the port are other reasons for this argument. Presence of oil rigs in which oil loading and discharge take place may be another reason for pollution caused by heavy metals in the region. Of course, numerous environmental events including the greatest oil contamination in the Persian Gulf (the first war of Persian Gulf, which caused 11 million gallons of oil entering the gulf) should not be neglected on high levels of oil pollution.

Regarding the adverse effects of different sources of pollution on ecosystem, it is crucial to estimate the pollution rate. Nickel and vanadium concentrations were the highest among other metals based on our findings. Since these two metals are seen as oil pollution parameters and the region is rich in oil, it can be concluded that oil pollution is widespread in the region as a result of excessive amount of such metals. The existing oil pollution threatens all the living organisms in the area.

\section{References}

1. Ballan-Dufrancais C, Jeantet AY, Geffard A, Amiard JC, AmiardTriquet C. Cellular and tissular distribution of copper in an intrasedimentary bivalve, the Baltic clam Macoma balthica, originating from a clean or a metal-rich site. Can J Fish Aquat Sci. 2001;58(10):1964-74.

2. Regional Organization for the Protection of the Marine Environment . Manual of oceanographic observations and pollutant analyses methods (MOOPAM):: Regional Organization for the Protection of the Marine Environment; 1999.

3. Al-Abdali F, Massoud MS, Al-Ghadban AN. Bottom sediments of the Arabian Gulf--III. Trace metal contents as indicators of pollution and implications for the effect and fate of the Kuwait oil

\section{slick. Environ Pollut.1996;93(3):285-301.}

4. de Mora S, Fowler SW, Wyse E, Azemard S. Distribution of heavy metals in marine bivalves, fish and coastal sediments in the Gulf and Gulf of Oman. Mar Pollut Bull. 2004;49(5-6):410-24.

5. Pourvakhshouri Z. Promotion of sustainable tourism in coastal regions. Environ Prot Agy Quart. 1998;24(3):24-38.

6. Canli M, Atli G. The realationships between heavy metal dissolved in sea water and influences of sex and size on metal accumulation and tissue distribution in the Norway IobsterNephropsnorvegicus. Mar Environ Res. 2003;36:217-23.

7. Roozbahani MM.. Investigation on species diversity of benthic Invertebrates as indicators of healthy environment in Bahrakan coastal region.. : Islamic Azad University, Sciences and Researches Branch; 2009.

8. Safahieh A, Farhad M, Ghanemi K, Movahedinia A, Darabpour M, Nabavi SMB. Accumulation of heavy metals of $\mathrm{Ni}, \mathrm{V}, \mathrm{Cu}$ and $\mathrm{Pb}$ in sediment and of bivalve Crass ostreagigasin Emam Khomeini Port. Oceanography Magazine. 2010;200:45-59.

9. Ravera O, Trincherini PR, Beone GM, Maiolini B. The trend from 1934 to 2001 of metal concentrations in bivalve shells (Unio pictorum) from two small lakes: Lake Levico and Lake Caldonazzo (Trento Province, Northern Italy). J Limnol. 2005;64(2):113-8.

10. Dadollahi S, Savari A, Safahieh A, Einollahi F. Investigation on the potential use of bivalve shells of Saccostreacucullata for biological monitoring of heavy metals $(\mathrm{Pb}, \mathrm{Cu}, \mathrm{Ni})$ in tidal coasts of Chabahar. Environ Sci Quart. 2011;50(24-38).

11. Yap CK, Ismail A, Tan SG, Omar H. Correlations between speciation of $\mathrm{Cd}, \mathrm{Cu}, \mathrm{Pb}$ And $\mathrm{Zn}$ in sediment and their concentrations in total soft tissue of green-lipped mussel Perna viridis from the west coast of Peninsular Malaysia. Environ Int. 2002;28(1-2):117-26.

12. Eugene Ng YJ, Yap CK, Zakaria MP, Tan SG. Assessment of Heavy Metal Pollution in the Straits of Johore by Using Transplanted Caged Mussel, Perna viridis. Pertanika J Sci Technol. 2013;21(1).

13. Gillikin DP, Dehairs F, Baeyens W, Navez J, Lorrain A, Andre L. Inter- and intra-annual variations of $\mathrm{Pb} / \mathrm{Ca}$ ratios in clam shells (Mercenaria mercenaria): a record of anthropogenic lead pollution? Mar Pollut Bull. 2005;50(12):1530-40.

14. Wright DA, Mihursky JA, Phelps HL. Trace metals in Chesapeake Bay oystersintra-sample variability and its implications for biomonitoring. Mar Environ Res. 1985;16:181-197.

15. Veerasingam S, Raja P, Venkatachalapathy R, Mohan R, Sutharsan P. Distribution of petroleum hydrocarbon concentrations in coastal sediments along Tamilnadu coast, India. Carpath J Earth Env. 2010;5(2):5-8.

16. El Tokhi M, Abdelgawad E, Lotfy MM. Impact of Heavy Metals and Petroleum Hydrocarbons Contamination of the East Port Said Port area, Egypt. J App Sci Res. 2008;4(12):1788-98. 